Health and Place in Historical Perspective: Medicine, Ethnicity, and Colonial Identities Author(s): Catharine Coleborne and Angela McCarthy

Reviewed work(s):

Source: Health and History, Vol. 14, No. 1, Special Issue: Health and Place: Medicine, Ethnicity, and Colonial Identities (2012), pp. 1-11

Published by: Australian and New Zealand Society of the History of Medicine

Stable URL: http://www.jstor.org/stable/10.5401/healthhist.14.1.0001

Accessed: 08/01/2013 16:39

Your use of the JSTOR archive indicates your acceptance of the Terms \& Conditions of Use, available at http://www.jstor.org/page/info/about/policies/terms.jsp

JSTOR is a not-for-profit service that helps scholars, researchers, and students discover, use, and build upon a wide range of content in a trusted digital archive. We use information technology and tools to increase productivity and facilitate new forms of scholarship. For more information about JSTOR, please contact support@jstor.org. 


\section{Health and Place in Historical \\ Perspective: Medicine, Ethnicity, and Colonial Identities}

\section{Catharine Coleborne and Angela McCarthy}

This Special Issue includes articles first presented as papers at a two-day symposium held at the University of Waikato, New Zealand, in February 2011. ${ }^{1}$ The event was designed to highlight a large Royal Society of New Zealand Marsden-funded research project, and to showcase current scholarly work in the field of the colonial and postcolonial histories of medicine, with a focus on histories of insanity. We also included the themes of medical migration in New Zealand's national history, the movement of medical ideas and personnel across empire, a close study of the uses of the term 'neurasthenia' in French-colonial Vietnam, and the relationship between place, plants, and health across South Asia and Australia in the nineteenth century.

These topics were put into a broader scholarly context in an engaging keynote presentation focusing on health and place by Robin Kearns. As one of the editors of the journal Health and Place, Robin Kearns was interested to make connections in his address between this journal and the symposium, which focused on history. Speaking about the ways in which a concept of 'place' might be fully utilised, Kearns examined the 'constellation of aspects' of place, including the notions of belonging, inclusion and exclusion, and the multiple dimensions of place: it might be a location, or a locale, or a sense of place, or a felt place. By stretching the 'traditional' spatial meanings of place among geographers, Kearns argued, we might understand more deeply the significance of 'place' for sectors of our own society, for instance, in the worlds of discharged psychiatric patients. ${ }^{2}$ Kearns talked about the crosscurrents in his own discipline of geography and its variety of uses for the term 'place,' also showing how geography and history might intersect along the lines of a shared fascination with heritage, memory, remembering, and understanding 
specific places and sites. In addition, Kearns' own work with cultural-geography colleagues focusing on the meanings of the abandoned psychiatric institution as a space and a place again provided audiences with a potent link between geography and history as modes of inquiry. ${ }^{3}$ Robin Kearns expands on his own symposium contribution in an invited reflective essay for this Special Issue.

Cross-disciplinary work in our respective fields of cultural geography and cultural history are becoming more common, and yet traversing disciplines to connect these themes in scholarship can prove more difficult. The concept of 'health and place' allowed the first editors of the journal Health and Place to draw connections between health and its situationsthe ways in which health is shaped by its location, and the meanings attached to places. ${ }^{4}$ Is health and place, then, a focus on 'historical geography,' or something more than historical understandings of places and locations? Graham Moon's first Editorial for that journal in 1995 argued that by (re)placing health, 'health' itself might be located in both space and time, and within a new field of inquiry. ${ }^{5}$ Articles included studies of social theory and medical geography, as well as studies of local environments in Glasgow and health care in Chile. Subsequent issues of the journal focused on health in the Pacific region as well as other colonial sites. ${ }^{6}$

Health and place, broadly conceived, was one way for our symposium speakers, all academic historians, to engage with the central focus of our research: medicine, ethnicity, and colonial identities. We aim to situate colonial health intellectually through discussions of both practices of health management inside institutions, as well as through interpretations of the implications and meanings of this management in later periods, following the so-called 'end' of colonisation. By doing this, we hope to stretch definitions of health and place beyond the significance of 'location,' and to historicise specific places and the discourses these produced. Colonial medicine has been the subject of numerous studies, beginning with the important volume, Disease, Medicine and Empire, edited by Roy McLeod and Milton Lewis and published in 1988. ${ }^{7}$ Historians including David Arnold and Warwick Anderson have added to the body of work by making leading contributions to the discussion of imperial and colonial health. Arnold's own 
synthesis of medicine and colonialism, together with his studies of disease in colonial India, suggested research pathways for historians of other colonial settings. ${ }^{8}$ Arnold also draws useful distinctions between types of colonies, and thus sets apart the settler colonialism of white settler colonies from the style of colonialism exhibited by different European imperial powers in parts of Africa, for example. ${ }^{9}$ Anderson, meanwhile, offered a cogent analysis of postcolonial histories of health and medicine in his chapter for Locating Medical History, edited by Frank Huisman and John Harley Warner, arguing that historians had for a long time tried to refresh the study of diseases, in particular through their examinations of tropical medicine, also taking histories of medicine beyond a national history framework. ${ }^{10}$ As Anderson points out, studies of tropical medicine by Michael Worboys stimulated new generations of historians in Britain to look outside the national systems of medicine and health. ${ }^{11} \mathrm{By}$ interrogating colonial medicine, Anderson points out, historians in the 1990s also came to focus on the ways in which the identities of the 'coloniser and colonised' were framed through medicine itself. ${ }^{12}$ His study of the colonial Philippines, where the American colonisers practiced tropical medicine on the bodies of the colonised population, situates and describes this process through a documentation of the development of public health, a theme also examined by Lenore Manderson in colonial Malaya. ${ }^{13}$

The very fact of newer physical and intellectual historical sites for the investigation of health practices over time also led historians to consider the identities of different actors in the medical fields, including patients as the subjects of medicine. The study of colonial identities in medicine is highlighted by Mary Sutphen and Bridie Andrews in their edited collection, Medicine and Colonial Identity (2003). They signal that in colonial settings, 'colonial subjects' had to come to terms with the "identity labels that colonizers applied to them.' ${ }^{14}$ Most of the essays in their book consider non-white identities being produced through colonialist interventions into health in the nineteenth and twentieth centuries. However, none of the work in the Sutphen and Andrews book considers histories of psychiatry. Yet, Anderson reminds us, the colonial asylum as an institution has received major attention as one explicit site for the formation of colonial medical and social identities. ${ }^{15}$ 
By now, those of us working in the histories of psychiatry are familiar with the rich work in the field which accentuates the question of colonialism and its shaping of patient worlds inside colonial institutions in the former European colonies, particularly the British colonies. This scholarship follows on the heels of decades of work focusing on the Anglo-American world of institutional confinement which also examines questions of gender, class, and in more limited ways, race and ethnicity, by looking at patient case-records. Given all of this activity, it is certainly prudent to wonder what more can be said, and what new ideas might be conveyed, about psychiatric institutions as sites of identity construction. To this range of historical studies we can add new sites of investigation, such as newer studies of psychiatry in the Pacific, or those recent works which describe the difference in parts of Africa settled in the nineteenth century by Europeans. ${ }^{16}$ 'Place,' then, remains important, even while we are seeking to disturb its edges and borders.

For example, Julie Parle writes about Natal and Zululand from the 1860 s to 1918 . Parle locates populations of the 'mad' who are quintessentially 'colonial': a mix of ethnic groups, some displaced indigenous peoples, Europeans, and migrants from other parts looking for work. In many ways Parle's selection of the period, and this population, compares in really interesting ways to Canada, parts of the Pacific (Fiji), or even Australasia, although these are not comparisons Parle pursues. Meanwhile, Lynette Jackson's Surfacing Up provides an excellent example of a critical and theoretical medical history of a postcolonial site through a sustained analysis of the colonial policies around psychiatric confinement and their effects in Southern Rhodesia (now Zimbabwe). Jackson's work invites comparisons with studies of colonial India and asylums for 'natives,' in particular, the work of Jim Mills. ${ }^{17}$ Both Jackson and Mills are intrigued by the 'women interrupted' or travelling women in the societies they examine; Jackson examines mobile women who were arrested 'out of place,' while Mills studies the 'wanderers' in the context of colonial India who were taken into asylum care. Such attention to the spatiality of colonial rule is important, because it reveals more about the colonial asylum's project within its social and political context.

Therefore new studies of institutions, populations, and ways inside this rich archive of patient records are always appearing. 
From transnational and transcolonial studies, as well as those that situate psychiatry within the frame of 'empire,' to others that are beginning to look at extra-institutional worlds of caring for the insane, scholars find a seemingly never-ending array of topics for consideration. ${ }^{18}$ In 2012, Angela McCarthy and Catharine Coleborne published their edited collection Migration, Ethnicity, and Mental Health: International Perspectives, 1840 2010, which again draws together significant new scholarship in the wider field. ${ }^{19}$ Taking a different approach-one centred on the relationships between health and place, as well as the formation of colonial identities - the articles in this Special Issue also reflect on new places, personnel, themes, and ways to discover past psychiatric practices. Certainly, as we suggest below, new work on ethnicity, religion, transnational or British World contexts, diagnoses of specific conditions, and the ways in which professional knowledge has been shared across sites, break new ground.

This issue includes papers from the symposium reframed as articles from a range of scholars, including new work from postgraduate students, work from a number of scholars wellknown in their respective fields, and as already mentioned, the final reflective piece from Kearns about health and place, which offers our readership some new ways of thinking about these ideas in both a cross-disciplinary and also an historical perspective. Caitlin Murray's important work about indigenous inmates of psychiatric institutions in Australia was also presented at our symposium, and we look forward to seeing her work published elsewhere in future. Murray spoke about the psychiatrist John Bostock, born in Scotland in 1892, who practiced as a psychologist and senior psychiatrist in Australia, and published works on the history of Australian psychiatry during the twentieth century. How was it, asked Murray, that Bostock hardly understood the complexity of his indigenous subjects? Who were his intellectual influences, and was his inability to 'see' Aboriginal people a product of his own history? Health and History readers will know of Murray's influential article published in a previous issue of the journal. ${ }^{20}$ Different speakers on the first day addressed the symposium themes 
through a range of physical, geographical, biographical, and intellectual frameworks. Imagining the international medical network as a 'place,' for instance, John Armstrong's paper took us to the concept of medical networks across space and time. James Beattie also ventured outside New Zealand and Australia looking beyond the white settler colonies and at the larger world patterns of which these places are part; talking about health migration, Beattie also conveyed a strong sense of the transmission of ideas across places in the nineteenth century, with ideas about the healing properties of places in India compared to similar locations in Australasia, and models of health care proposed within the context of a mobile population of migrants, military men, and colonists. Whether the healthy 'places' of empire were interchangeable, at least, within discursive constructions of these, raised important questions about the rubric of 'health and place.' These topics are also discussed below as we outline the contents of this Special Issue with an emphasis on how the articles also addressed the subtheme of medicine and colonial identities.

The issue begins with an article by Angela McCarthy. McCarthy's contribution to this issue situates New Zealand's lunatic asylums in their broader transnational, national, and local contexts. While acknowledging that Britain and Ireland had quite different approaches to asylum care, commentators tend to stress the influences of the homelands in Australasia. Yet considerable differences also existed between asylum care in New Zealand and the homelands as McCarthy reveals in examining three aspects generating medical comment: asylum provision and funding, statistics, and forms of committal. McCarthy points to these issues generating concern because of claims that insane patients were being shipped to New Zealand, that the colony had high admission and recovery rates, and that asylums were overcrowded. McCarthy also highlights some differences between asylums in the colony, particularly as revealed through statistics, in which patient demographics and causes of insanity contrasted from place to place. Differences in asylum conditions and maintenance charges also generated comparative comment.

Linked to this discussion, Maree Dawson re-examines some well-known ideas about concerns over 'racial degeneracy' in New Zealand. Although such anxieties are often located as early 
twentieth-century ones, Dawson finds evidence that from the 1850s, patient case notes at the Auckland Asylum (later called the Auckland Mental Hospital) show a growing interest in the effects of heredity and a burgeoning discourse of white racial decline. By situating this within a larger white settler colonial world in terms of the international, empire-wide transmission of medical theories, Dawson also broadens the scope of knowledge about the local work of Auckland's institution for the insane in the second half of the nineteenth century. Close attention to the patient notes, as well as to medical biography, medical journals, and their travelling contents, suggests that scholarship has tended to neglect the inner workings of nineteenth-century mental hospitals as sites that generated forms of knowledge about the emerging theory of eugenics.

Elspeth Knewstubb, meanwhile, draws on sources from New Zealand's only private asylum, Ashburn Hall in Dunedin, to explore patient expressions of Christian religious identity. Prominent in studies of New Zealand's history by scholars such as John Stenhouse, religion has received little attention in studies of the country's asylums. Yet as Knewstubb shows, religious language, imagery, delusions, and observance demonstrate the meaningful role of religion in patients' lives and recognition by doctors of the therapeutic value of religious belief and practice. Themes of sin and salvation, Heaven and Hell, God and the Devil emerge from patient case books, though Knewstubb makes an important methodological point by acknowledging that description of such content varied from doctor to doctor. Knewstubb suggests that delusions may have conveyed patients' alienation at being in an unfamiliar place removed from family and surroundings. She also stresses that religious worship was not just an important place and space in the community, but also in the asylum.

Patients' identities inside the institutions for the insane are again the focus in Catharine Coleborne's article, this time with emphasis on the colony of Victoria, Australia, but also showing how Auckland's population in the institution for the insane might be usefully compared in the same period. Coleborne argues that historians of 'the empire' interested in gender and sexuality have not viewed the hospitals for the insane as useful terrain to locate and analyse forms of socially constructed colonial and imperial identities. By looking again at patient cases for their 
value as social texts which described marginalised peoplesincluding new immigrants or foreign-born settlers in colonial Victoria who found themselves institutionalised-Coleborne makes a strong case for the full examination of patient cases in relation to social disadvantage. In particular, the article takes cases of immigrant and foreign-born women in the Yarra Bend Asylum in the mid- to late-nineteenth century, also suggesting a powerful comparison with the inmates at Auckland Asylum in the same period.

Moving away from the nineteenth-century hospitals for the insane, but again considering the meaning of 'empire' by taking readers back to larger questions of imperialism, health, and people across places, James Beattie argues for an imperial landscape of health in his article about place, and the movement of plants and people between India and Australia in the final decades of the nineteenth century. This 'powerful triumvirate of health,' as Beattie puts it, draws attention to the belief in balancing the worlds of migrants - the mobile people of the colonial period - with the places they traversed, and the plants that also moved between sites. This article nicely describes the complexities forged by imperialism itself. The identities of places and people, then, were forged by contact and difference, and also by the search for common spaces and modes of health such as the hill stations sought after by Europeans.

Meanwhile, in urban French Vietnam, the colonial genealogy of 'neurasthenia' was still being asserted in the twentieth century, as demonstrated by Laurence Monnais. Monnais examines the local identity and spatiality of the problem of 'neurasthenia,' a diagnosis born with modernity and applied in urban settings to the Vietnamese, but also with their assent: again, the hegemony of medical diagnoses becomes a useful tool for thinking about forms of colonialism. This 'medicalisation of Vietnamese nervousness' was linked to global processes, expressed locally, and can be seen in a range of ways across the medical field, as Monnais eloquently suggests. Resting on a deep analysis of rich newspaper and print materials, the article shows that the French viewed the diagnosis in two ways - as both affirmation of the success of colonial rule or presence, and also as a tool of continued colonialism.

Writing within the field of colonial psychiatry, Monnais refers to the work of Hans Pols in the Dutch East Indies, which 
is also included in this issue. Here, however, Pols is focused on a biography of the Dutch colonial psychiatrist, F. W. Theunissen. Theunissen was the medical director of several large mental hospitals, and became the director of the Dutch East Indies Public Health Service by the 1930s. Primarily remembered as an administrator, Theunissen's career, viewed within the scholarship of histories of colonial psychiatry, suggests revisiting medical biography as well as the question of administrative functions of institutional care and the institutions' different directors to grasp the full picture of colonial experiences. Through a fresh understanding of the gamut of what makes 'colonial medicine' (institutions, cultural elements, clashes of styles of understanding health, and so on), Pols subtly interrogates the term. A colonial 'identity' for institutions might be less an effect of place than personnel and personality.

Finally, addressing aspects of international medical and health networks, as well as New Zealand histories of medical professionals in the twentieth century, John Armstrong very effectively shows that the identities of New Zealand doctors could not help but be shaped by an international field of medicine, including the impacts of training, professional qualifications, and personal experiences of the network of professional medical exchanges. Armstrong uses published medical autobiographies and medical obituaries, among other sources, to locate his discussion about the significance of an international medical network for New Zealand medical specialists. Like other writers in this issue, Armstrong also addresses important methodological and critical issues in writing histories of medicine by showing how these can be used to further disturb dominant constructions of national, international, colonial, and imperial, histories. Read together, the articles in this Special Issue raise many questions about the relationships between 'health' and 'place,' and still others about what it means to talk about 'medicine' and 'colonial identities.' We hope that readers and historians take up some of these questions in future research.

University of Waikato and University of Otago, New Zealand 
1. Titled "Health and Place: Medicine, Ethnicity and Colonial Identities," the event of 24 and 25 February 2011 showcased the Royal Society of New Zealand Marsden-funded project UOO-167-SOC, led by Professor Angela McCarthy and Associate Professor Catharine Coleborne: "Migration, Ethnicity and Insanity in New Zealand and Australia, 1860-1910." We gratefully acknowledge this fund, as well as the Faculty of Arts and Social Sciences Contestable Research Fund, the University of Waikato, for sponsoring this event, and we thank the authors for their fine contributions and engagements with the peer reviewing process.

2. Robin Kearns, "Re-Placing Health: Looking Beyond Location in Institutional Histories of Care," Invited Keynote address to Health and Place Symposium, University of Waikato, 24 February 2011.

3. See for example, Alun E. Joseph, RobinA. Kearns, and Graham Moon, "Recycling Former Psychiatric Hospitals in New Zealand: Echoes of Deinstitutionalisation and Restructuring," Health \& Place 15, no. 1 (2009): 79-87.

4. See also for example, Hester Parr and Chris Philo, 'A Forbidding Fortress of Locks, Bars and Padded Cells': The Locational History of Mental Health Care in Nottingham, Historical Geography Research Series 32 (London: Historical Geography Research Series, 1996), 1-98; Hester Parr, "Bodies and Psychiatric Medicine: Interpreting Different Geographies of Mental Health," in Mind and Body Spaces: Geographies of Illness, Impairment and Disability, edited by Ruth Butler and Hester Parr (London: Routledge, 1999), 181-202. See also a Special Issue of Health and Place on this topic: 6 , no. 3 (2000).

5. Graham Moon, Editorial: "(Re)Placing Research on Health and Health Care," Health and Place 1, no. 1 (1995): 1-4.

6. Special Issue: "Islands, Health and Development," Health and Place 1, no. 4 (1995).

7. Disease, Medicine and Empire, edited by Roy McLeod and Milton Lewis (London: Routledge, 1988).

8. David Arnold, "Medicine and Colonialism," in Companion Encyclopedia of the History of Medicine, Vol. 2, edited by W. F. Bynum and Roy Porter (London: Routledge, 1997), 1393-1416; Arnold, “'An Ancient Race Outworn': Malaria and Race in Colonial India, 1860-1930," in Race, Science and Medicine, 1700-1960, edited by Waltraud Ernst and Bernard Harris (London: Routledge, 1999), 123-43.

9. Arnold, "Medicine and Colonialism," 1402.

10. Warwick Anderson, "Postcolonial Histories of Medicine," in Locating Medical History: The Stories and Their Meanings, edited by Frank Huisman and John Harley Warner (Baltimore: Johns Hopkins University Press, 2004).

11. Ibid., 290.

12. Ibid., 295.

13. Warwick Anderson, Colonial Pathologies: American Tropical Medicine, Race, and Hygiene in the Philippines (Durham: Duke University Press, 2006); Lenore Manderson, Sickness and the State: Health and Illness in Colonial Malaya, 1870-1940 (New York: Cambridge University Press, 1996).

14. Mary Sutphen and Bridie Andrews, Medicine and Colonial Identity (London: Routledge, 2003), 2.

15. Anderson, "Postcolonial Histories of Medicine," 297.

16. See Jacqueline Leckie, "The Embodiment of Gender and Madness in Colonial Fiji," Fijian Studies 3, no. 2 (2005): 311-36. References to studies of Africa follow below, but we might include here Canada: see for instance James E. Moran and David Wright, eds, Mental Health and Canadian Society: Historical Perspectives (Montreal and Kingston: McGill-Queens University Press, 2006).

17. James H. Mills, Madness, Cannabis and Colonialism: The 'Native Only' Lunatic Asylums of British India, 1857-1900 (Basingstoke: Palgrave Macmillan, 2000).

18. Sloan Mahone and Megan Vaughan, eds, Psychiatry and Empire (Basingstoke: Palgrave, 2007); Waltraud Ernst and Thomas Mueller, eds, Transnational Psychiatries: Social and Cultural Histories of Psychiatry in Comparative Perspective, c. 1800-2000 
(Newcastle Upon Tyne: Cambridge Scholars Publishing, 2010).

19. Angela McCarthy and Catharine Coleborne, eds, Migration, Ethnicity, and Mental Health: International Perspectives, 1840-2010 (London: Routledge, 2012).

20. Caitlin Murray, "The 'Colouring of the Psychosis': Interpreting Insanity in the Primitive Mind," Health and History 9, no. 2, (2007): 7-21 [Special Issue on 'Aboriginal Health and History']. 